GEOLOGICA BALCANICA, 40. 1-3, Sofia, Dec. 2011, p. 75-83.

\title{
The "Selinitsa-Drakos" coastal karstic system in the Messinian Mani Peninsula (southwestern Greece) in relation to the terrestrial geoenvironment
}

\author{
Kyriaki Papadopoulou-Vrynioti ${ }^{1}$, Isidoros Kampolis ${ }^{2}$
}

\author{
${ }^{1}$ Faculty of Geology and Geoenvironment, University of Athens, Platanon 16b, 14578, Athens, Greece, \\ email:papadopoulou@geol.uoa.gr \\ ${ }^{2}$ Odyssea Elyti 15, 13341, Athens, Greece, email: kampolisi@yahoo.gr \\ (Accepted in revised form: November 2011)
}

\begin{abstract}
The studied coastal karstic system comprises "Selinitsa" Cave and "Drakos" Underground River. It is located in southwestern Greece across the western coastline of the Messinian Mani Peninsula. It is developed into limestones of Upper Senonian to Upper Eocene age belonging to the Mani geotectonic unit. "Selinitsa" is mainly developed above the sea level, whereas "Drakos" is under water down to $-48 \mathrm{~m}$. These two caves are now connected through a $28-\mathrm{m}$ long narrow passage at depth of $-28 \mathrm{~m}$, thus creating a united karstic system. Both caves were initially separate and terrestrial. Today, the majority of cave passages of "Selinitsa" are terrestrial. In "Senitsa-Drakos" karstic system, sequential karstification base levels have been identified. These levels determined the karstic system development. "Selinitsa" passages are phreatic and vadose, whereas "Drakos" passages are only phreatic, acting as lifting tubes. The passage network of both caves presents dentritic pattern and comprises the hydrological equivalent of the surface drainage network. To the east of the karstic system, karst margin plains are present comprising karstified tectonic terraces, whereas above the "Selinitsa-Drakos" system manmade terraces exist for agricultural purposes.
\end{abstract}

Papadopoulou-Vrynioti, K., Kampolis, I. 2011. The "Selinitsa-Drakos" coastal karstic system in the Messinian Mani Peninsula (southwestern Greece) in relation to the terrestrial geoenvironment. Geologica Balcanica 40(1-3), 75-83.

Key words: "Selinitsa" cave, "Drakos" Underground River, terrestrial, hydrological equivalent network, speleomorphology.

\section{INTRODUCTION}

The studied "Selinitsa-Drakos" coastal karstic system is located in southwestern Greece, at the western coast of the Messinian Mani Peninsula, $46 \mathrm{~km}$ southeast of Kalamata city, in western Mani municipality. It comprises the cave of "Selinitsa" and the underground river of "Drakos" (Papadopoulou-Vrynioti, 1999, 2002). Both karstic forms are located at the coastline: "Selinitsa" - at $1 \mathrm{~km}$ south of Agios Dimitrios village, and "Drakos" - at $500 \mathrm{~m}$ south of "Selinitsa". The entrance of "Selinitsa" is located at $10 \mathrm{~m}$ above the sea level and "Drakos" is accessible only underwater.

This study aims at clarifying the relation between "Selinitsa-Drakos" underground coastal karstic system and the terrestrial geoenvironment.

\section{GEOLOGY}

This karstic system is developed into typical whitegrey to white, medium-bedded platy semi-crystalline limestones of Upper Senonian to Upper Eocene age, 300-500 m thick, belonging to the Mani (Plattenkalk) geotectonic unit (Fig. 1). In wider area, slightly metamorphic flysch of Upper Eocene - Oligocene age and silicate schists of Lower - Middle Jurassic age occur stratigraphically above the Upper Senonian - Upper Eocene limestones. Pantokrator limestones of Middle Triassic - Lower Jurassic age crop out at the lower stratigraphic level of Mani Unit (Papanikolaou et al., 1990). Post-Alpine Late Cenozoic clastic deposits, Pliocene marine marls and Pleistocene clays are observed in unconformity along the coastal zone (Kelletat 
and Gassert, 1975). Late Pleistocene and Holocene fans cover the plain areas.

The tectonics of the studied area is represented by faults of NNW-SSE orientation and minor E-W orientation, mainly formed during the Miocene (Mariolakos et al., 1985) which affected the whole Mani Peninsula. Since the Middle Pleistocene, the stresses in the area are being reversed to extensional with WNW-ESE direction.

\section{GEOMORPHOLOGY}

Karst margin plains were recognized during the fieldwork in the wider area of the caves. They are located between 160-200 $\mathrm{m}$ and 200-240 m (Fig. 2), developed on the Upper Senonian - Upper Eocene limestones. PostMiocene karst margin plains were developed south of the studied area (Stocker, 1976). Karst margin plains consti-

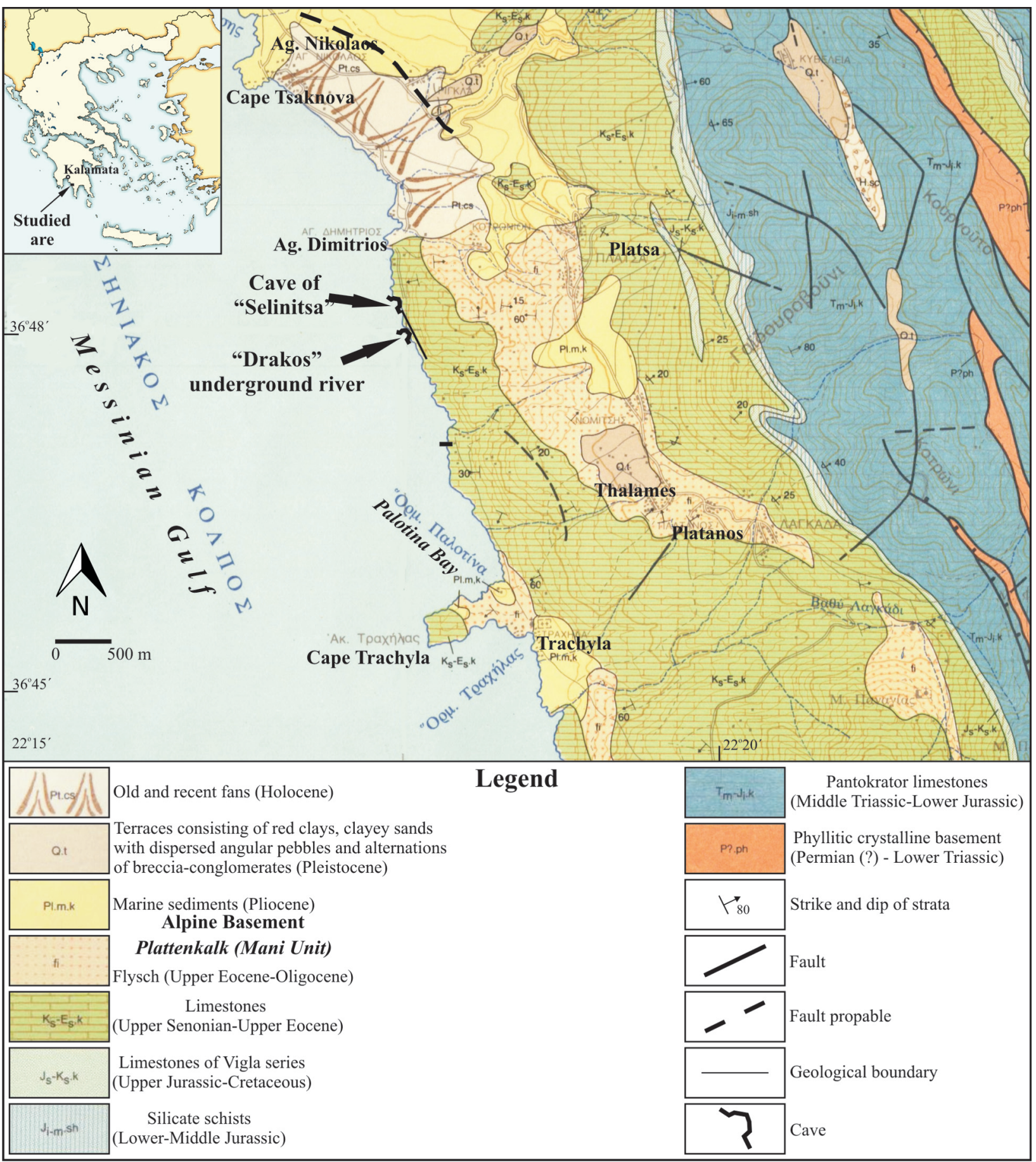

Fig. 1. Geological map of the studied area (IGME, 1983) modified 
tute karstified tectonic terraces therefore they reflect the uplift of the area.

Manmade anthropogenic terraces were recognized above the caves. They are constructed at altitudes of 200-220 m and comprise also artificial agricultural fields for the olive tree cultivation.
The drainage network is of dendritic type north of "Selinitsa" and south of "Drakos". It is represented mainly by small drainage branches of $1^{\text {st }}, 2^{\text {nd }}$ and $3^{\text {rd }}$ classes. The biggest streams are "Stepenitsa" Stream north of Agios Dimitrios and "Vathi Lagadi" Stream south of Trachila. According to Strahler's scale "Stepenitsa" is

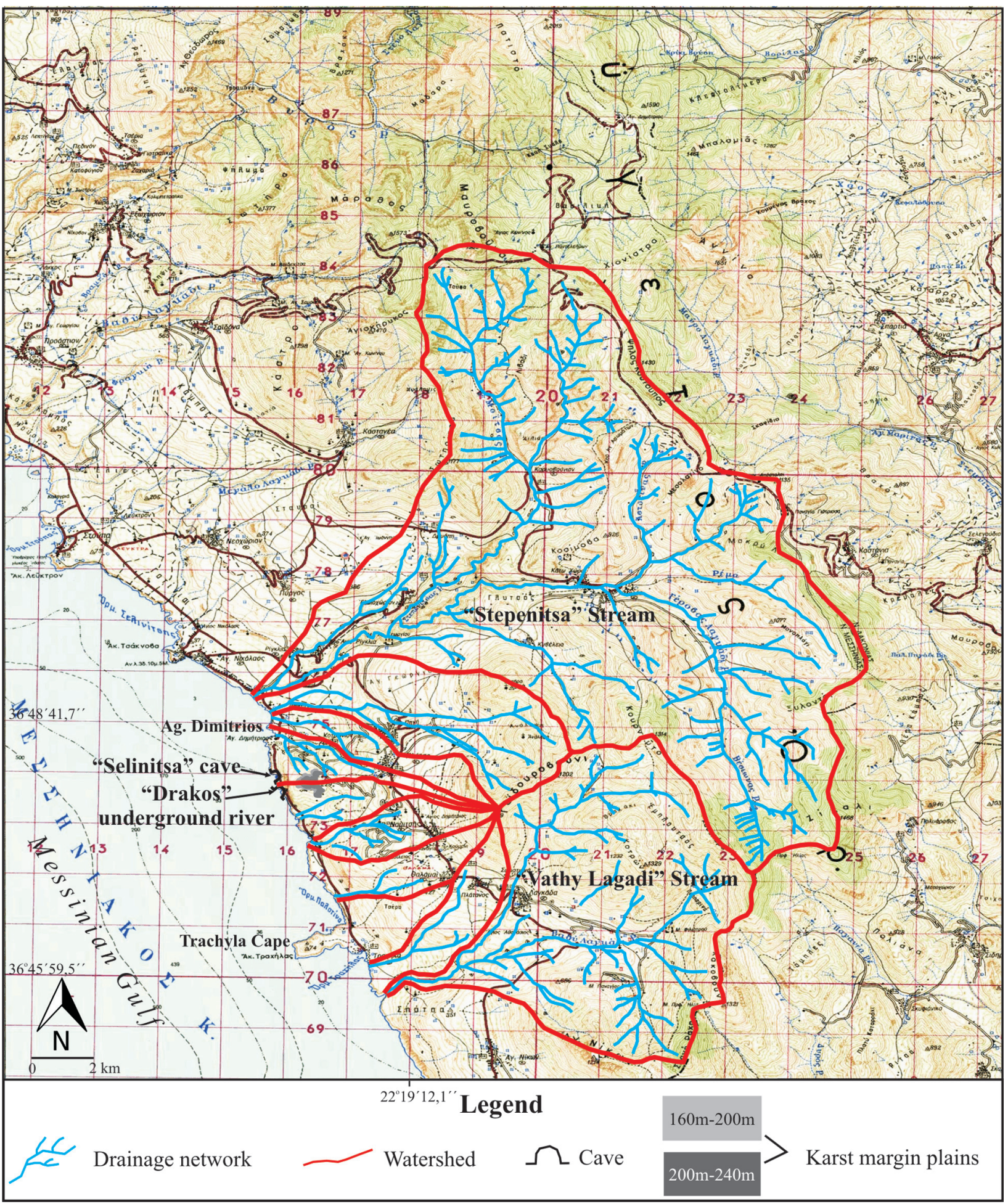

Fig. 2. Topographic map of the studied area with the karst margin plains and drainage networks 
a $5^{\text {th }}$ class stream (Fig. 2) and "Vathi Lagadi" is a $4^{\text {th }}$ class stream.

Based on the rose diagrams of drainage network branch directions (Fig. 3, Tables 1 and 2) in the studied area, we conclude that the drainage network branches to the north of "Selinitsa" are developed mainly in NW-SE, NNW-SSE and E-W directions. On the contrary, south of "Drakos" these branches are mainly of NE-SW to E-W directions.

Notable are the Holocene alluvial fans in "Stepenitsa" Stream. These fans have been created due to fault activity of NW - SE direction which was recognized during the fieldwork.

\section{SPELEOMORPHOLOGY}

The underground river of "Drakos" has length of about $1232 \mathrm{~m}$ and is composed of three levels (Fig. 4). The development of "Drakos" begins some centimeters above the sea level reaching depth of $-48 \mathrm{~m}$. The first level appears with limited speleothematic decoration. The beginning of the cave represents a room with dimensions $50 \mathrm{~m} \times 100 \mathrm{~m}$ which has two entrances, $10 \mathrm{~m}$ and $6 \mathrm{~m}$ wide, respectively. At the eastern entrance of "Drakos" Underground River

Table 1

Drainage network directions, north of Selinitsa in degrees (203 datasets)

\begin{tabular}{rrrrrrrr}
\hline 300 & 286 & 246 & 220 & 182 & 126 & 317 & 336 \\
300 & 322 & 174 & 168 & 290 & 142 & 272 & 36 \\
272 & 234 & 180 & 262 & 320 & 220 & 264 & 336 \\
270 & 336 & 180 & 257 & 232 & 210 & 270 & 42 \\
279 & 340 & 186 & 198 & 217 & 222 & 204 & 40 \\
274 & 290 & 216 & 111 & 190 & 232 & 268 & 96 \\
280 & 326 & 164 & 80 & 232 & 227 & 343 & 352 \\
168 & 322 & 164 & 90 & 252 & 221 & 334 & 281 \\
146 & 354 & 234 & 6 & 270 & 154 & 352 & 306 \\
140 & 278 & 216 & 60 & 200 & 190 & 310 & 348 \\
100 & 172 & 220 & 350 & 228 & 180 & 278 & 344 \\
52 & 166 & 216 & 64 & 278 & 164 & 290 & 346 \\
100 & 148 & 136 & 17 & 224 & 125 & 326 & 304 \\
106 & 153 & 220 & 24 & 190 & 160 & 330 & 30 \\
94 & 162 & 115 & 348 & 252 & 224 & 46 & 352 \\
58 & 163 & 118 & 338 & 216 & 168 & 75 & 48 \\
114 & 110 & 108 & 324 & 216 & 178 & 92 & 354 \\
88 & 142 & 156 & 320 & 190 & 224 & 102 & 343 \\
138 & 258 & 216 & 342 & 274 & 174 & 170 & 28 \\
244 & 258 & 0 & & & & & \\
\hline
\end{tabular}
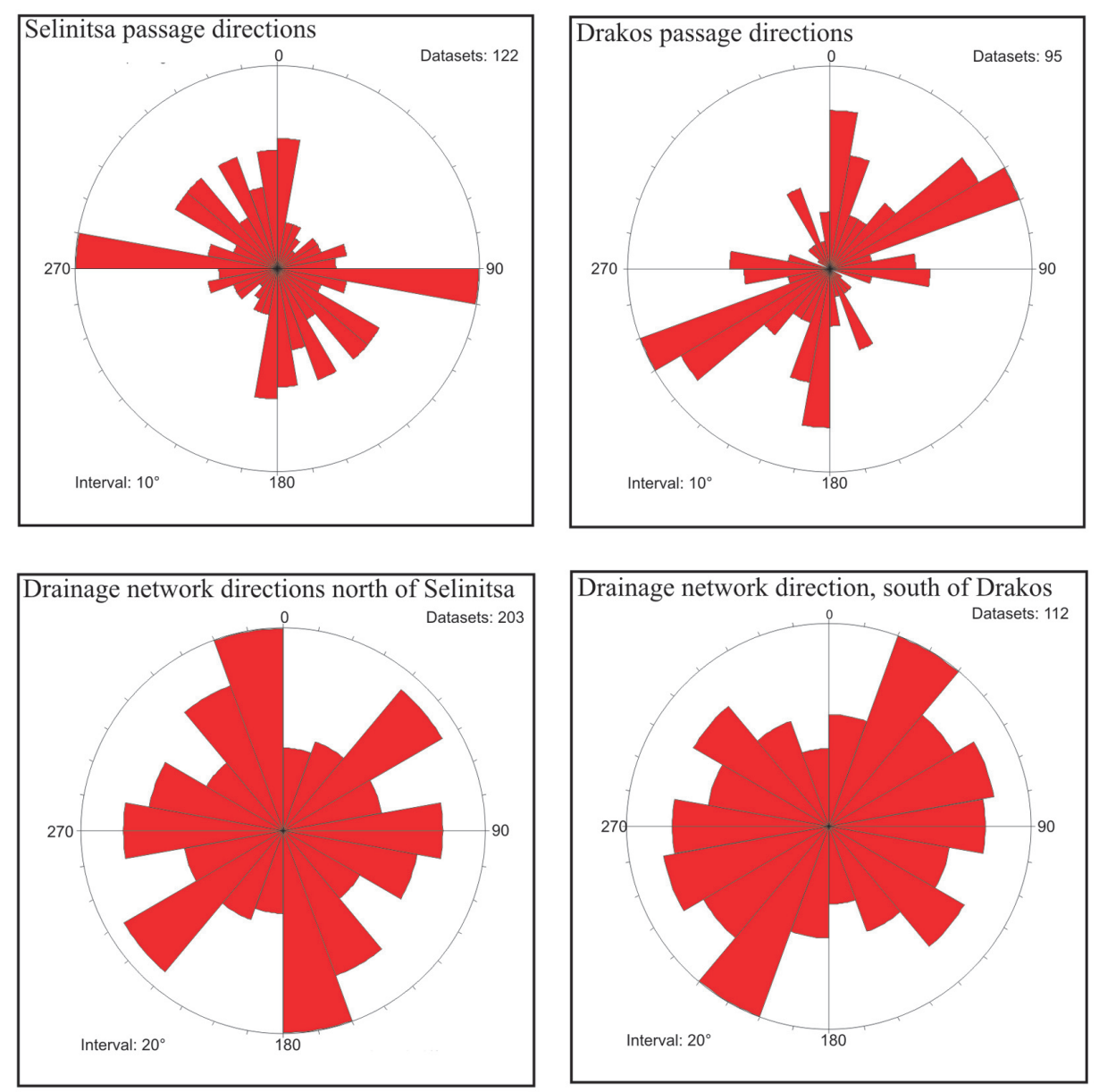

Fig. 3. Rose diagrams of network development directions and cave passage directions 
Table 2

Drainage network directions, south of Drakos in degrees (112 datasets)

\begin{tabular}{llllllll}
\hline 277 & 252 & 197 & 200 & 288 & 300 & 176 & 274 \\
254 & 272 & 220 & 264 & 334 & 330 & 272 & 216 \\
236 & 290 & 220 & 270 & 247 & 272 & 308 & 316 \\
246 & 220 & 282 & 310 & 202 & 300 & 264 & 274 \\
280 & 186 & 210 & 154 & 237 & 334 & 250 & 146 \\
244 & 217 & 184 & 172 & 264 & 316 & 133 & 130 \\
250 & 188 & 262 & 246 & 250 & 340 & 166 & 150 \\
212 & 230 & 284 & 200 & 258 & 316 & 194 & 202 \\
300 & 184 & 250 & 215 & 210 & 286 & 172 & 150 \\
220 & 214 & 212 & 180 & 216 & 232 & 240 & 234 \\
294 & 226 & 200 & 150 & 180 & 292 & 200 & 210 \\
298 & 236 & 204 & 124 & 262 & 316 & 244 & 176 \\
252 & 256 & 180 & 192 & 324 & 298 & 205 & 170 \\
288 & 330 & 220 & 302 & 238 & 262 & 302 & 276 \\
\hline
\end{tabular}

there is a big stalagmite. Only part of this room is above the sea level. The length is almost $400 \mathrm{~m}$. The first and the second levels are connected through a chimney-shaped fissure, $13 \mathrm{~m}$ high, which reaches depth of $-18 \mathrm{~m}$. This chimney occurs $100 \mathrm{~m}$ away from the "Drakos" entrance.

The length of the second level is about $281 \mathrm{~m}$ and it connects with the third level through a chimney-shaped fissure, too. In the second level, the presence of speleothematic material is restricted.

The third level is the deepest part of the underground river where the connection point between "Selinitsa" cave and "Drakos" Underground River is located (Koryllos et al.,, 2004). This point lies at depth of $-28 \mathrm{~m}$ (Fig. 4) in a room which is actually transverse to the main passageway. There, through a narrow vertical chimney-shaped passage, 28-m long, one passes into the cave of "Selinitsa". The total length of this level is approximately $551 \mathrm{~m}$.

The development altitudes of the above mentioned levels correspond to sequential karstification base levels,
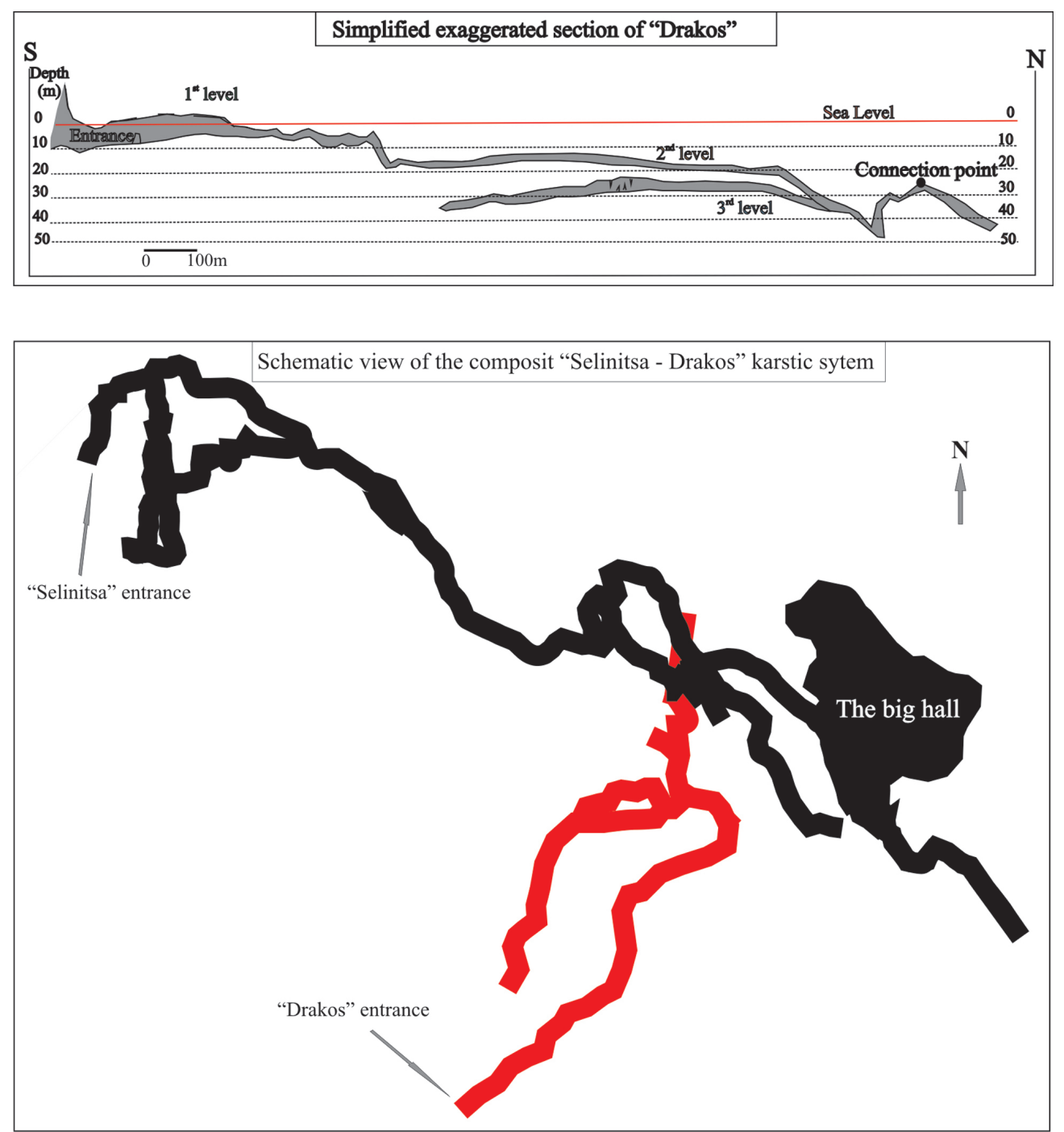

Fig. 4. Simplified exaggerated section of "Drakos" with the three levels after Crossley (1985) modified by Kampolis and schematic view of the composite "Selinitsa-Drakos" karstic system 


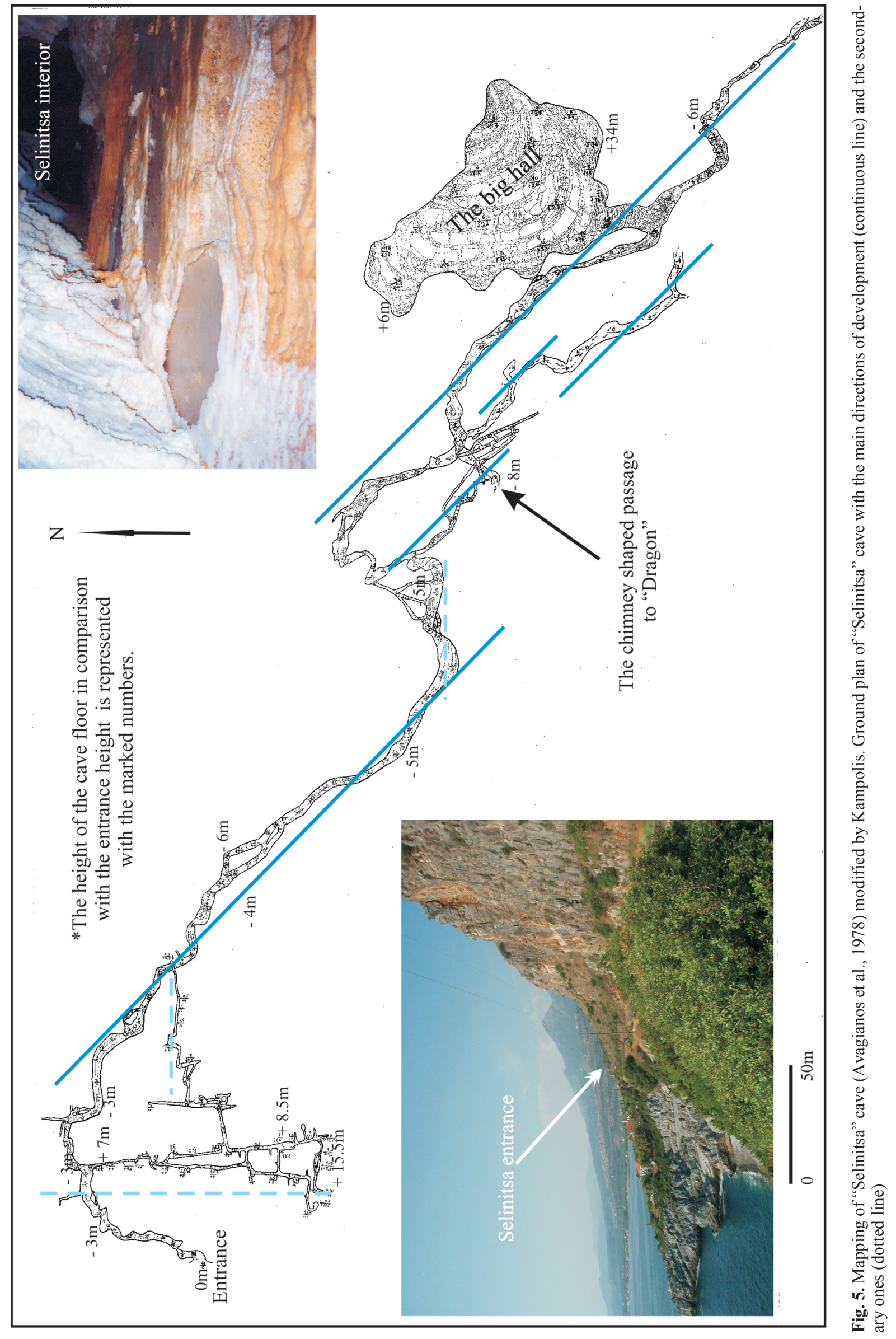


the oldest among them lying at depth of $-48 \mathrm{~m}$. This process was probably related to the sea-level changes during the Holocene (Lambeck, 1995).

"Selinitsa" cave (Fig. 5) has a total length of about $3 \mathrm{~km}$ and recovers fabulous speleothematic decoration. Its largest part extends mostly above the sea level and only a relatively small part of it (approximately $1000 \mathrm{~m}$ ) appears flooded. Via this part, water is discharged towards the "Drakos" Underground River. "Selinitsa" is famous with the largest uniform hall in Greece, with dimensions $250 \mathrm{~m} \times 200 \mathrm{~m}$ of the main axes but without speleothematic decoration due to sequential colapses.

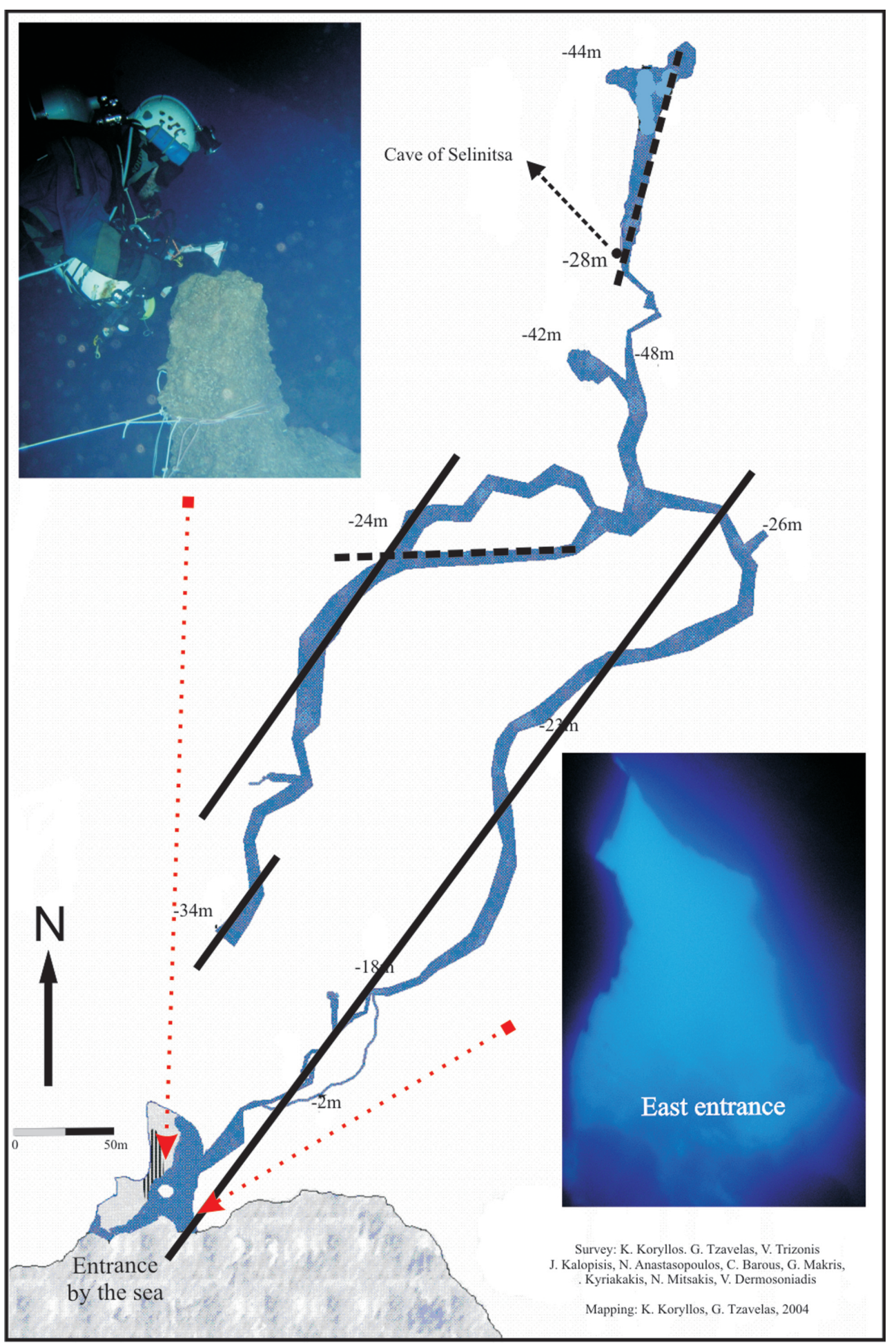

Fig. 6. Mapping of "Drakos" Underground River (Koryllos et al. 2004) modified by Kampolis. Ground plan of the underground river of "Drakos" with the main directions of development (continuous line) and the secondary ones (dotted line). Survey: Koryllos et al., 2004 
The passages of this coastal karstic system are vadose and phreatic in "Selinitsa" and exclusively phreatic in "Drakos". "Drakos" siphons act as lifting tubes, transferring water from "Selinitsa", from depths of $-28 \mathrm{~m}$ up to $-10 \mathrm{~m}$. The passage network of this karstic system belongs to the dendritic type of underground karst forms (Fig. 4), while this network diverges to the upward direction.

Analysis of "Selinitsa" mapping (Fig. 5) in relation to the rose diagrams of its cave passage directions (Fig. 3, Table 3) shows that the larger part of passageway development is of NW orientation, and small sections - of E-W direction. The main axis of the big hall in "Selinitsa" is of NW-SE and E-W orientation. The part of "Selinitsa" where the connection passage with "Drakos" exists appears to be of NE-SW orientation. Additionally, short passageways are developed along $\mathrm{N}-\mathrm{S}$ directions. The majority of "Drakos" passages are of $\mathrm{N} 30^{\circ} \mathrm{E}, \mathrm{N} 32^{\circ} \mathrm{E}$ orientation and only a small part of them - of $\mathrm{N} 98^{\circ}$ orientation (Fig. 6, Table 4).

By comparison of the rose diagrams of the branch development directions of the surface network north of "Selinitsa" and south of "Drakos" with the rose diagrams of the cave passage directions in "Selinitsa" and "Drakos" (Fig. 4, Tables 1-4), it has been concluded that

Table 3

Selinitsa passage directions in degrees (122 datasets)

\begin{tabular}{rrrrrrrr}
\hline 0 & 130 & 135 & 311 & 90 & 6 & 232 & 336 \\
100 & 144 & 80 & 296 & 40 & 358 & 98 & 314 \\
82 & 118 & 120 & 232 & 98 & 352 & 162 & 300 \\
18 & 92 & 90 & 318 & 63 & 350 & 128 & 35 \\
72 & 180 & 170 & 290 & 90 & 348 & 90 & 276 \\
2 & 120 & 135 & 334 & 5 & 275 & 140 & 248 \\
25 & 32 & 75 & 338 & 108 & 270 & 28 & 270 \\
64 & 142 & 170 & 306 & 38 & 256 & 80 & 284 \\
22 & 266 & 50 & 300 & 90 & 270 & 322 & 317 \\
335 & 0 & 160 & 288 & 190 & 4 & 356 & 330 \\
0 & 22 & 108 & 250 & 120 & 350 & 152 & 356 \\
60 & 348 & 154 & 278 & 70 & 270 & 98 & 19 \\
0 & 10 & 122 & 317 & 100 & 255 & 85 & 52 \\
129 & 7 & 154 & 330 & 165 & 334 & 352 & 312 \\
352 & 0 & 128 & 326 & 112 & 314 & 96 & 220 \\
166 & 340 & & & & & & \\
\hline
\end{tabular}

Table 4

Drakos passage directions in degrees (95 datasets)

\begin{tabular}{rrrrrrrr}
\hline 0 & 190 & 285 & 335 & 50 & 340 & 220 & 190 \\
50 & 180 & 240 & 335 & 60 & 355 & 190 & 240 \\
50 & 210 & 235 & 340 & 60 & 15 & 200 & 250 \\
60 & 220 & 265 & 320 & 80 & 325 & 170 & 260 \\
20 & 330 & 230 & 315 & 75 & 270 & 270 & 240 \\
20 & 275 & 260 & 5 & 60 & 300 & 230 & 190 \\
5 & 245 & 270 & 5 & 60 & 330 & 230 & 230 \\
355 & 280 & 270 & 250 & 5 & 355 & 60 & 240 \\
0 & 220 & 270 & 270 & 10 & 0 & 330 & 30 \\
10 & 265 & 280 & 190 & 315 & 0 & 210 & 220 \\
30 & 245 & 230 & 240 & 50 & 0 & 220 & 260 \\
50 & 200 & 225 & 230 & 335 & 60 & 0 & \\
\hline
\end{tabular}

both branches and cave passages follow the same directions. Consequently, the specific dendritic caves are the underground hydrologic equivalent of the surface dendritic networks of the studied area.

\section{CONCLUSIONS}

The coastal cave of "Selinitsa" and the "Drakos" Underground River were initially terrestrial as it is ascertained by the existence of speleothematic material in both caves. The two caves were primarily separate. They were connected into uniform karstic system in recent geologic times as their connection point is only a narrow chimney-shaped passage, its width corresponding to younger karstification base level.

The levels and the observed widening in the two caves correspond to sequential karstification base levels.

The underground karstic system of "Selinitsa-Drakos" represents underground hydrological equivalent of the surface drainage network as both belong to the dendritic type and the development directions of cave passages are the same with the drainage branch directions of the surface network.

Karst margin plains east of this karstic system comprise karstified tectonic terraces and display the tectonic uplift in the area. The sequential scalable and plain surfaces above this karstic system comprise anthropogenic cultivation terraces. Alluvial fans of the "Stepenitsa" Stream are being formed due to regional tectonic activity.

\section{REFERENCES}

Avagianos, G., Zoupis, K., Patirati, Th., Koniari, H. 1978. Mapping of "Selinitsa" cave, Ag. Dimitrios, Messinian Mani (in Greek with English abstract).

Crossley, W., G. 1985. Mapping of Spring "Drakos", Southern Greece: Explored and Surveyed 1982 and 1985. Cave Diving Group (GDG).
IGME. 1983. Geological map, sheet "Xirokampion" Scale 1:50000 (Psonis, C., Latsoudas. Ch., Explanatory note in Greek with English abstract).

Kelletat, D., Gassert, D. 1975. Die Formengruppe Pediment - Glatthang - Felsfacher der westlichen Mani Halbinsel, Peloponess. Die Erde 106, 174-192. 
Koryllos, K., Tzavellas, G., Trizonis, V., Kalopsis, J., Anastasopoulos, N., Barous, C., Makris, G., Kiriakakis, G, Mitsakis, N., Dermosoniadis, V. 2004. Mapping of the underground river of "Dragon", Ag. Dimitrios, Messinian Mani. Speleo (in Greek with English abstract).

Lambeck, K. 1995. Late Pleistocene and Holocene sea-level change in Greece and SW Turkey: a separation of eustatic, isobatic and tectonic contributions. Geophysical Journal International 122, 1022-1044.

Mariolakos I., Papanikolaou, D., Lagios, E. 1985. A neotectonic geodynamic model of Peloponnesus based on: morphotectonics, repeated gravity measurements and seismicity. Geologisches Jahrbuch Band 50, 3-17.

Military Geographic Service, 1991. Topographic sheet 'Xirovounion', 1:50000.
Papadopoulou-Vrynioti, K. 1999. Zusammenfassenede Bemerkugen über Verbreitungen, Nutzung und Sdutz der Karstgebiete Griechenland. Die Hohle, 5, 548-552.

Papadopoulou-Vrynioti, K. 2002. Lost rivers and hazard pollution. $6^{\text {th }}$ Int. Symposium on History of Speleology and Karstology, ALCADI, Gorizia, Italy, 55-61.

Papanikolaou, D., Paquin, C., Bloyet, J., Foudoulis, D., Moschopoulos, P. 1990. In site stress measurements in Messinia after the 1986 Kalamata earthquakes. Bulletin Geological Society of Greece, 24, 95-101.

Stocker, E. 1976. Klimamorphologische Untersuchungen auf der Mani Halbinsel mit besonderer Berucksichtigung der Formengruppe Glatthang-Pediment-Karstrandebene. Arbeits Geografisches Institut, Univsität Salzburg, 6, 91-228. 